\title{
Stability indicating RP-HPLC method for the simultaneous estimation of ivabradine and metoprolol in bulk and tablet formulation
}

\author{
Sangameshwar B. Kanthale ${ }^{1 *}$, Sanjay S. Thonte ${ }^{2}$, Debarshi Kar Mahapatra ${ }^{1}$ \\ ${ }^{1}$ School of Pharmacy, Swami Ramanand Teertha Marathwada University, Nanded, India. \\ ${ }^{2}$ Channabasweshwar Pharmacy College, Latur, India.
}

\begin{tabular}{l}
\hline ARTICLE INFO \\
\hline Received on: 10/12/2018 \\
Accepted on: 11/02/2019 \\
Available online: 18/04/2019 \\
\hline Key words: \\
Ivabradine, metoprolol, \\
simultaneous, validation, \\
degradation, stability studies.
\end{tabular}

\section{INTRODUCTION}

Ivabradine (IVA), 3-[3-[(3,4-dimethoxy-7-bicyclo[4.2.0] octa-1,3,5-trienyl)methyl-methylamino]propyl]-7,8-dimethoxy2,5-dihydro-1H-3-benzazepin-4-one (Fig. 1a) is a direct and selective inhibitor of the hyperpolarization-activated cyclic nucleotide-gated $\left(\mathrm{I}_{\mathrm{f}}\right)$ channel current in the pacemaker cells of the sinoatrial node of the heart (DiFrancesco and Camm, 2004). It is used for the symptomatic management of stable heartrelated chest pain and heart failure not fully managed by beta blockers (Gokhroo et al., 2016). It decreases the myocardial oxygen consumption while increasing diastolic time, without affecting myocardial contractility or coronary vasomotor tone

\section{"Corresponding Author}

Sangameshwar Kanthale, Research Scholar, School of Pharmacy, Swami Ramanand Teertha Marathwada University, Nanded, India. E-mail: sangamkanthale@gmail.com
(Kaski et al., 2018). Metoprolol (MET), 1-(isopropylamino)-3[4-(2-methoxyethyl)phenoxy]propan-2-ol (Fig. 1b) is a selective $\beta_{1}$ receptor blocker used to treat high blood pressure, chest pain due to poor blood flow to the heart, and a number of conditions involving an abnormally fast heart rate (HR) (Zarifis et al., 2016). It often remains the drugs of choice for reducing $\mathrm{HR}$ in CHF with reduced ejection fraction (Volterrani and Iellamo, 2016). IVA hydrochloride in combination with MET succinate or tartrate in use for the treatment of inappropriate sinus tachycardia and in acute inferior wall STEMI patients for lowering the HR with a significantly lesser risk of AV blocks (Ptaszynski et al., 2013). This combination significantly improves the symptoms and quality of life in patients with stable angina pectoris (Werdan et al., 2016). It is available in the market as IMPLICOR ${ }^{\circledR}$, IVAMET XL ${ }^{\circledR}$, etc., brand in the form of film coated tablet containing $5 \mathrm{mg}$ IVA with $25 \mathrm{mg}$ MET or $7.5 \mathrm{mg}$ IVA with $50 \mathrm{mg}$ MET.

So far, numerous reports employing validated analytical reverse phase-high-performance liquid chromatography (RPHPLC) (Maheshwari et al., 2010), ultra-performance liquid 


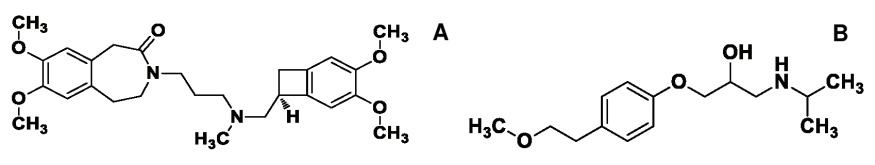

Figure 1. Structure of (a) ivabradine and (b) metoprolol.

chromatography tandem mass spectrometry (Sun et al., 2015), fluorescence (Cui et al., 2010), and spectrophotometric (Mostafa et al., 2017) methods for individual estimation of IVA and its metabolic products ( $\mathrm{Li}$ et al., 2011) in plasma (rat, rabbit, and human) (Ranjha et al., 2017; Zoerner et al., 2013), bulk formulation, and pharmaceutical formulation (capsule, controlled release product, and tablet) (Patra and Panda, 2014; Rehman and Nagamallika, 2017; Seerapu and Srinivasan, 2010) by the global researchers have been into applications.

While going through the literature available in the standard global databases, not a single report have been found regarding any analytical RP-HPLC method for the routine simultaneous estimation of IVA and MET drug combination in bulk and pharmaceutical formulation along with validated stability indicating data. Understanding the fact, a simple, robust, precise, economical, and accurate method was developed to meet the challenge. The present work endeavors development of a validated stability indicating RP-HPLC method for simultaneous estimation of IVA and MET in bulk and tablet formulation.

\section{MATERIALS AND METHODS}

\section{Materials}

A generous gift sample of IVA and MET was obtained from SL Drugs and Pharmaceuticals Ltd., Hyderabad. The IVAMET XL ${ }^{\circledR}$ containing $5 \mathrm{mg}$ of IVA and $25 \mathrm{mg}$ of MET was purchased from Ajanta Pharma Ltd., Mumbai. Analytical grade chemicals (HiMedia Ltd., Mumbai) and HPLC grade solvents were employed for the study. The weighing was done on Shimadzu ${ }^{\circledR}$ AUW220D (Kyoto, Japan) balance. The pH was measured on VSI $^{\circledR}$ VSI-1B digital pH meter (Mohali, India). Sonication was performed on Transonic Digital S sonicator (Mumbai, India). The method was developed on a reverse phase Denali $\mathrm{C}_{18}$ column of dimension $150 \mathrm{~mm} \times 4.6 \mathrm{~mm}$ having $5 \mu \mathrm{m}$ particle size connected to a Waters ${ }^{\circledR} 2695$ HPLC system equipped with PDA detector 2996 along with a manual rheodyne injector $(20 \mu \mathrm{l}$ loop), controlled by EMPOWERS v.2 software.

\section{Selection of the mobile phase}

The selection of the mobile phase is very critical for the elution of the solutes. The mobile phase was selected on the basis of theoretical plates, peak purity index, and peak symmetry. The trial commenced using the buffer systems with an eluant such as methanol, acetonitrile, etc. The elution with buffer $\mathrm{KH}_{2} \mathrm{PO}_{4}$ : methanol in equal ratio produced low-intensity peaks with a high tailing. $\mathrm{KH}_{2} \mathrm{PO}_{4}$ buffer $(\mathrm{pH} 4.8)$ with acetonitrile led to the appearance of the broad peak with tailing, but an improvement was noticed in comparison to the previous trial. When the buffer was replaced with orthophosphoric acid (OPA) (0.1\%), a significant excellence in the peak symmetry and reduced tailing was observed when used along with methanol in equal ratio but was still not suitable to elute the solutes. For further perfection, the acetonitrile was employed along with OPA to get sharp peak with ideal Gaussian peak. The ratio of 60:40 v/v provided the highest peak purity index and the greatest number of theoretical plates. The mobile phase was degassed using the vacuum and filtered through $0.45 \mu \mathrm{m}$ membrane filter. The mobile phase was allowed to equilibrate until a steady baseline was obtained.

\section{Chromatographic conditions}

IVA and MET were eluted with OPA (0.1\%) buffer: acetonitrile in the ratio of $60: 40 \mathrm{v} / \mathrm{v}$ in a 6 minutes isocratic trial at a flow rate of $0.8 \mathrm{ml} /$ minute having an ambient column temperature of $30^{\circ} \mathrm{C}$ and monitored at $260 \mathrm{~nm}$ wavelength.

\section{Preparation of analytical solutions}

Preparation orthophosphoric acid (0.1\%) buffer

An accurately weighed quantity of OPA $(1 \mathrm{ml})$ was diluted with 1,000 $\mathrm{ml}$ of HPLC grade water and further degassed by sonication.

\section{Preparation of mobile phase}

The above-prepared buffer was thoroughly mixed with acetonitrile in the ratio of $60: 40 \mathrm{v} / \mathrm{v}$. The solution was then degassed by sonicating for the period of 5 minutes and filtered through $0.45 \mu \mathrm{m}$ membrane filter under vacuum.

\section{Diluent preparation}

A 60:40 V/V ratio of water and acetonitrile was employed as the diluent for the preparation of the standard solution and the sample solution.

\section{Standard preparation}

An accurate amount of $5 \mathrm{mg}$ IVA and $25 \mathrm{mg}$ MET were added to $25 \mathrm{ml}$ dry volumetric flask and $5 \mathrm{ml}$ of diluent was added. The above content was sonicated for 10 minutes and the volume was made up to $10 \mathrm{ml}$ to produce $500 \mathrm{ppm}$ of IVA and 2,500 ppm of MET. Then, $1 \mathrm{ml}$ of the produced content was pipetted out in a $10 \mathrm{ml}$ volumetric flask and the volume was diluted to $10 \mathrm{ml}$ to produce 50 and $250 \mathrm{ppm}$ of the content.

\section{Sample preparation}

Five tablets were weighed accurately and the average weight was calculated accordingly. In a $100 \mathrm{ml}$ of volumetric flask, weight equivalent to a tablet was transferred and half-filled with the diluent. The content was sonicated for the period of 20 minutes and filtered suitably to produce $500 \mathrm{ppm}$ of IVA and 2,500 ppm of MET. Then, $1 \mathrm{ml}$ of the solution was transferred to a volumetric flask of $10 \mathrm{ml}$ volume and diluent was added to produce 50 and $250 \mathrm{ppm}$ of the content.

\section{Method validation}

According to the $\mathrm{Q} 2 \mathrm{~A}$ and $\mathrm{Q} 2 \mathrm{~B}$ guidelines of the International Council for Harmonisation (ICH) of Technical Requirements for Pharmaceuticals for Human Use and in compliance with the United States Food and Drug Administration (USFDA) guidance, the proposed method was validated. 


\section{Linearity and range}

The linearity of the method was estimated by taking six concentrations of the solutes in the range of $5-30 \mu \mathrm{g} / \mathrm{ml}$ for IVA and $25-150 \mu \mathrm{g} / \mathrm{ml}$ for MET. The solutions were prepared with the diluent and equivalent volume was injected into the HPLC system to determine the peak area. A linearity graph was plotted between the concentration and average area for each solute. The regression coefficient value $\left(r^{2}\right)$ was also determined (Sawale et al., 2017).

\section{Accuracy}

The accuracy (recovery) was determined by spiking the standard drug solutions at concentrations of 50\%, 100\%, and $150 \%$ in the HPLC system. The study was performed in a triplicate way with data expressed in the form of $\%$ recovery $\pm \%$ relative error on the basis of definite concentrations (Deodhe et al., 2017a).

\section{Precision}

The precision of the developed method was estimated in terms of inter-day and intra-day variability by spiking the concentrations of $50 \%, 100 \%$, and $150 \%$ six times in a single day (intra-day) and also on three different days (inter-day). The data were expressed in precision $\pm \%$ relative error (Deodhe et al., 2017b).

\section{Robustness}

The robustness of the method was judged by deliberately altering the mobile phase composition by $\pm 5 \%$ v/v (i.e., $65: 35 \%$ $\mathrm{v} / \mathrm{v}$ and $55.45 \% \mathrm{v} / \mathrm{v}$ ), flow rate by $\pm 0.1 \mathrm{ml} /$ minute (i.e., 0.9 and $1.1 \mathrm{ml} /$ minute), and column temperature by $\pm 5^{\circ} \mathrm{C}$ (i.e., $25^{\circ} \mathrm{C}$ and $35^{\circ} \mathrm{C}$ ), keeping the other chromatographic parameters constant (Jha et al., 2017).

\section{Systems suitability parameters}

The reproducibility profile of the analytical method was estimated by injecting five-times the standard solution and recording the parameters such as retention time, peak area, theoretical plates, and tailing factor (Prakash et al., 2018).

\section{Limit of detection and quantification}

The limit of detection (LOD) may be defined as the lowest detectable concentration by any analytical method, but not necessary to measure the exact amount (Perumal et al., 2014).

The LOD was determined by the formula:

$\mathrm{LOD}=3.3(\sigma / S)$

Where $\sigma=$ standard deviation of response; $S=$ slope of the calibration curve. The slope $S$ may be estimated from the calibration curve of the analyte.

The limit of quantification (LOQ) may be defined as the lowest detectable concentration by any analytical method with a particular level of accuracy and precision (Bauer et al., 2014).

The LOQ is determined by the formula:

$\mathrm{LOQ}=10(\sigma / S)$

Where $\sigma=$ standard deviation of response; $S=$ slope of the calibration curve. The slope $S$ may be estimated from the calibration curve of the analyte.

\section{Degradation studies}

\section{Acid degradation studies}

$0.5 \mathrm{mg}$ of the equivalent amount of drug combination was taken in a $100 \mathrm{ml}$ volumetric flask and $50 \mathrm{ml}$ of the diluent was added. The content was sonicated for the duration of 15 minutes and the volume was made with the remaining amount of diluent. The content was stirred for half an hour and centrifuged for 5 minutes at 3,000 rpm. Five milliliters of the solution was taken carefully and mixed with equal volume of $2 \mathrm{~N} \mathrm{HCl}$. The content was allowed to boil for an hour and afterward neutralized with $2 \mathrm{~N} \mathrm{NaOH}$. The volume was made up to $100 \mathrm{ml}$ and filtered cautiously with $0.45 \mu \mathrm{m}$ membrane filter. Twenty microliters volume of sample was spiked into the system and the data were recorded.

\section{Alkali degradation studies}

$0.5 \mathrm{mg}$ of the equivalent amount of drug combination was taken in a $100 \mathrm{ml}$ volumetric flask and $50 \mathrm{ml}$ of the diluent was added. The content was sonicated for the duration of 15 minutes and the volume was made with the remaining amount of diluent. The content was stirred for half an hour and centrifuged for 5 minutes at 3,000 rpm. Five milliliters of the solution was taken carefully and mixed with equal volume of $2 \mathrm{~N} \mathrm{NaOH}$. The content was allowed to boil for an hour and afterward neutralized with $2 \mathrm{~N} \mathrm{HCl}$. The volume was made up to $100 \mathrm{ml}$ and filtered cautiously with $0.45 \mu \mathrm{m}$ membrane filter. Twenty microliters volume of sample was spiked into the system and the data were recorded.

\section{Oxidation degradation studies}

$0.5 \mathrm{mg}$ of the equivalent amount of drug combination was taken in a $100 \mathrm{ml}$ volumetric flask and dissolved in $5 \mathrm{ml}$ of $\mathrm{H}_{2} \mathrm{O}_{2}(30 \% \mathrm{w} / \mathrm{w})$. The content was boiled for an hour to initiate the oxidative stress-induced drug degradation. The content was diluted with diluent and the volume was made up to the mark. The content was centrifuged, supernatant was collected, and $20 \mu \mathrm{l}$ of volume was spiked into the system to record the data.

\section{Dry heat degradation studies}

$0.5 \mathrm{mg}$ of the equivalent amount of drug combination was taken in a $100 \mathrm{ml}$ volumetric flask and exposed to heat at $90^{\circ} \mathrm{C} \pm 1^{\circ} \mathrm{C}$ for 1 hour. The content was diluted with the diluent and stirred for 30 minutes, further sonicated, and the volume was made up to $100 \mathrm{ml}$. The content was centrifuged for 5 minutes time at 3,000 rpm, filtered, and $20 \mu \mathrm{l}$ of the volume was spiked into the HPLC system.

\section{RESULTS AND DISCUSSION}

\section{Method development and optimization of chromatographic conditions}

The novel method was based entirely on trials and errors as no previous similar methods are developed. However, some inspiration was drawn from the already available reports while selecting the stationary phase. The Denali reverse phase $\mathrm{C}_{18}$ stationary phase of dimension $250 \times 4.6 \mathrm{~mm}$ i.d., particle size $5 \mu \mathrm{m}$ was applied. The mobile phase OPA $(0.1 \%)$ : acetonitrile in the ratio of $60: 40 \mathrm{v} / \mathrm{v}$ 
was employed for the elution after several continuous trials run. A low $\mathrm{pH}$ was applied to the mobile phase as it ensured reduction in the peak tailing and significantly improves the robustness of the analytical method. Silica-based reverse phase columns are prone to dissolution due to high basic $\mathrm{pH}$, therefore the use of acidic $\mathrm{pH}$ was justified to a greater extent. It was also ascertained that the $\mathrm{pH}$ of the mobile phase remains in close agreement with the $\mathrm{pKa}$ of the solute to make them remain in the unionized state. Therefore, the $\mathrm{pH}$ value in accordance with two units was chosen. The elution was performed using Denali $\mathrm{C}_{18}$ column employing mobile phase OPA $(0.1 \%)$ : acetonitrile in the ratio of $60: 40 \mathrm{v} / \mathrm{v}$ in isocratic mode run for 6 minutes duration. The flow rate was maintained at $0.8 \mathrm{ml} /$ minute, keeping the column temperature at $30^{\circ} \mathrm{C}$, and detected at $260 \mathrm{~nm}$. The retention time of IVA and MET was found to be 2.290 and 3.520 minutes, respectively (Fig. 2a). The short-run method will conserve time and solvent and will provide peaks with better resolution. The tablet sample solution presented retention time of IVA at 2.289 minutes and for MET at 3.516 minutes (Fig. 2b). This undoubtedly revealed that the developed analytical method was precise, accurate, and robust for the routine analysis of the drug combination in bulk and tablet formulations.

\section{Method validation}

\section{Linearity and range}

Over the range of $10-30 \mu \mathrm{g} / \mathrm{ml}$ for IVA and $25-150 \mu \mathrm{g} /$ $\mathrm{ml}$ for MET, an exceptionally high linearity was observed between the dose and peak area with linear regression equations found to be $y=17451 x+755.43$ and $y=24280 x+4295.11$, respectively (Table 1). The regression coefficient values were 0.999 in both the cases which significantly represent a high degree of linearity (Fig. 3).

\section{Accuracy}

By the application of the calibration curve, the Y-intercept and the slope of the graph played a pivotal role in the
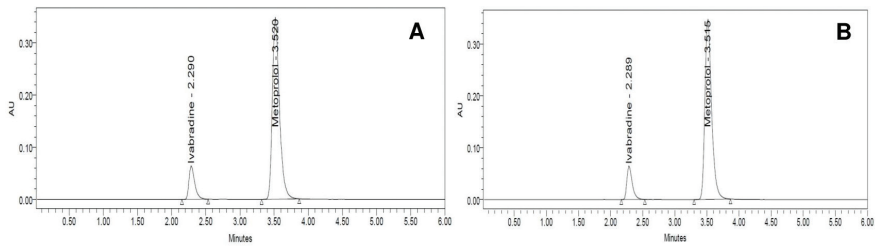

Figure 2. Chromatogram for ivabradine and metoprolol (a) after method optimization and (b) tablet sample solution.

Table 1. Linearity study of IVA and MET.

\begin{tabular}{ccccc}
\hline $\begin{array}{c}\text { Linearity } \\
\text { levels }\end{array}$ & \multicolumn{2}{c}{ IVA } & \multicolumn{2}{c}{ MET } \\
\hline $\mathbf{( \% )}$ & $\begin{array}{c}\text { Concentration } \\
(\boldsymbol{\mu g} / \mathbf{m l})\end{array}$ & $\begin{array}{c}\text { Peak area } \\
(\mathbf{m V})\end{array}$ & $\begin{array}{c}\text { Concentration } \\
(\boldsymbol{\mu g} / \mathbf{m l})\end{array}$ & $\begin{array}{c}\text { Peak area } \\
(\mathbf{m V})\end{array}$ \\
\hline 25 & 5 & 91,815 & 25 & 633,581 \\
50 & 10 & 175,590 & 50 & $1,219,283$ \\
75 & 15 & 260,273 & 75 & $1,808,568$ \\
100 & 20 & 349,645 & 100 & $2,430,079$ \\
125 & 25 & 428,697 & 125 & $3,003,949$ \\
150 & 30 & 531,783 & 150 & $3,681,392$ \\
\hline
\end{tabular}

determination of $\%$ recovery attribute of the proposed method for the simultaneous estimation. The established \% RSD values were $0.36,0.63$, and 0.36 for IVA and $0.63,0.78$, and 0.31 for MET, respectively, which was within the USP pharmacopeia acceptance limit of $\pm 2 \%$ (Table 2). Overall, the method signified good accuracy of the obtained recovery data.

\section{Precision}

In both the intra-day and inter-day variability studies for precision data, the method was found to be extremely precise over the tested range of $10-30 \mu \mathrm{g} / \mathrm{ml}$ for IVA and $25-150 \mu \mathrm{g} / \mathrm{ml}$ for MET. The peak area of the sample solution matched corresponding to the standard solution in both the cases, along with \% RSD of $<2 \%$. The $\%$ RSDs were observed to be in the range of $0.34 \%-$ $0.56 \%$ for IVA and $0.19 \%-0.39 \%$ for MET of the intra-day studies (Table 3), whereas the \% RSDs were observed to be in the range of $0.21 \%-0.36 \%$ for IVA and $0.26 \%-0.53 \%$ for MET in the inter-day studies (Table 4) which reflected a high precision and minimum variation of the developed method.
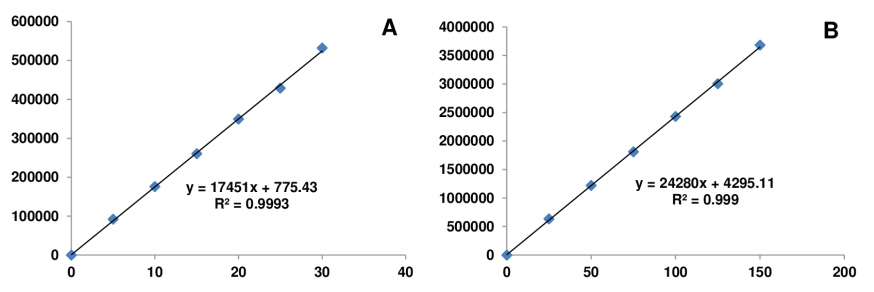

Figure 3. Linearity plot of (a) ivabradine and (b) metoprolol.

Table 2. Recovery for accuracy studies for the combination.

\begin{tabular}{|c|c|c|c|c|c|}
\hline $\begin{array}{c}\text { Spiked level } \\
(\%)\end{array}$ & $\begin{array}{c}\text { Conc. of } \\
\text { drug added } \\
(\mu \mathrm{g} / \mathrm{ml})\end{array}$ & $\begin{array}{l}\text { Conc. of } \\
\text { drug found } \\
(\mu \mathrm{g} / \mathrm{ml})\end{array}$ & $\begin{array}{c}\text { Recovery } \\
\text { (\%) }\end{array}$ & $\begin{array}{c}\text { Mean } \\
(\%)\end{array}$ & $\begin{array}{c}\% \\
\text { RSD }\end{array}$ \\
\hline \multicolumn{6}{|c|}{ Ivabradine } \\
\hline & 10 & 10.0871 & 100.87 & & \\
\hline \multirow[t]{3}{*}{50} & 10 & 10.0349 & 100.35 & 100.46 & 0.36 \\
\hline & 10 & 10.0185 & 100.18 & & \\
\hline & 20 & 19.9817 & 99.91 & & \\
\hline \multirow[t]{3}{*}{100} & 20 & 20.0347 & 100.17 & 99.68 & 0.63 \\
\hline & 20 & 19.7957 & 98.98 & & \\
\hline & 30 & 30.0311 & 100.10 & & \\
\hline \multirow[t]{2}{*}{150} & 30 & 29.8422 & 99.47 & 99.68 & 0.36 \\
\hline & 30 & 29.8422 & 99.47 & & \\
\hline \multicolumn{6}{|c|}{ Metoprolol } \\
\hline \multirow{3}{*}{50} & 50 & 49.8687 & 99.74 & & \\
\hline & 50 & 49.7921 & 99.58 & 100.02 & 0.63 \\
\hline & 50 & 50.3699 & 100.74 & & \\
\hline \multirow{3}{*}{100} & 100 & 99.7799 & 99.78 & & \\
\hline & 100 & 100.291 & 100.29 & 99.61 & 0.78 \\
\hline & 100 & 98.7558 & 98.76 & & \\
\hline \multirow{3}{*}{150} & 150 & 149.043 & 99.36 & & \\
\hline & 150 & 148.13 & 98.75 & 99.04 & 0.31 \\
\hline & 150 & 148.542 & 99.03 & & \\
\hline
\end{tabular}




\section{Robustness}

With the intentional variation in some key chromatographic parameters such as mobile phase composition, flow rate, and column temperature by $\pm 5 \%, \pm 0.1$, and $\pm 5^{\circ} \mathrm{C}$, a considerable change was observed in the chromatogram for both the drugs. When the mobile phase combination was varied to $65: 35$ $\mathrm{v} / \mathrm{v}$, the general retention peak of 2.290 minutes (IVA) and 3.520 minutes (MET) got shifted to 2.132 and 3.135 minutes, which was nearly $10 \%$ variation (Fig. 4a). In a similar manner, the alteration

Table 3. Precision data of intra-day variability.

\begin{tabular}{lccccc}
\hline Drug & $\begin{array}{c}\text { Conc. } \\
(\boldsymbol{\mu} \mathbf{g} / \mathbf{m l})\end{array}$ & $\begin{array}{c}\text { Peak area of } \\
\text { standard }(\mathbf{m V})\end{array}$ & $\begin{array}{c}\text { Peak area of } \\
\text { sample }(\mathbf{m V})\end{array}$ & $\begin{array}{c}\text { \% label } \\
\text { claim }\end{array}$ & \%RSD \\
\hline \multirow{4}{*}{ IVA } & 10 & 353,332 & 353,390 & 100.01 & 0.56 \\
& 20 & 353,861 & 356,608 & 100.77 & 0.41 \\
& 30 & 356,766 & 356,573 & 99.94 & 0.34 \\
\multirow{2}{*}{ MET } & 50 & $2,441,691$ & $2,451,819$ & 100.41 & 0.27 \\
& 100 & $2,455,467$ & $2,456,204$ & 100.03 & 0.39 \\
& 150 & $2,474,722$ & $2,447,927$ & 98.91 & 0.19 \\
\hline
\end{tabular}

Conc. $=$ concentration; $\mathrm{SD}=$ standard deviation; $\mathrm{RSD}=$ relative standard deviation .

Table 4. Precision data of inter-day variability.

\begin{tabular}{cccccc}
\hline Drug & $\begin{array}{c}\text { Conc. } \\
(\boldsymbol{\mu g} / \mathbf{m l})\end{array}$ & $\begin{array}{c}\text { Peak area of } \\
\text { standard }(\mathbf{m V})\end{array}$ & $\begin{array}{c}\text { Peak area of } \\
\text { sample }(\mathbf{m V})\end{array}$ & $\begin{array}{c}\text { \% label } \\
\text { claim }\end{array}$ & \%RSD \\
\hline \multirow{4}{*}{ IVA } & 10 & 338,983 & 338,106 & 99.74 & 0.36 \\
& 20 & 345,011 & 346,202 & 100.34 & 0.29 \\
& 30 & 346,218 & 345,215 & 99.71 & 0.21 \\
\multirow{2}{*}{ MET } & 50 & $2,338,248$ & $2,340,667$ & 100.10 & 0.53 \\
& 100 & $2,382,253$ & $2,387,851$ & 100.23 & 0.34 \\
& 150 & $2,404,741$ & $2,398,305$ & 99.73 & 0.26 \\
\hline
\end{tabular}

Conc. $=$ concentration; $\mathrm{SD}=$ standard deviation; $\mathrm{RSD}=$ relative standard deviation.
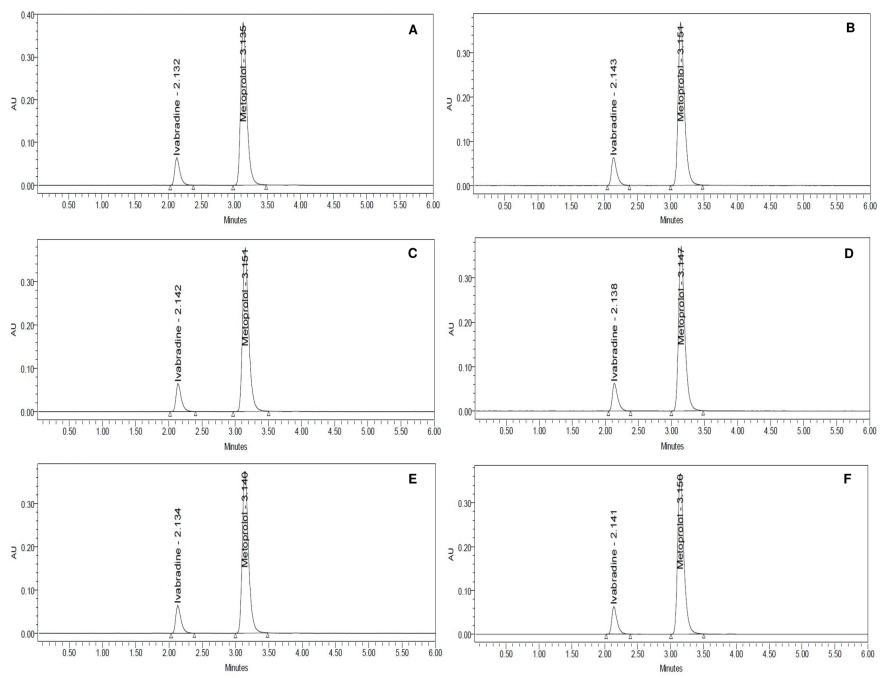

Figure 4. Robustness studies of ivabradine and metoprolol under (a) mobile phase composition 65:35 v/v; (b) mobile phase composition 55:45 v/v; (c) flow rate at $0.9 \mathrm{ml} /$ minute; (d) flow rate at $0.7 \mathrm{ml} /$ minute; (e) column temperature $35^{\circ} \mathrm{C}$; and (f) column temperature $25^{\circ} \mathrm{C}$. in the composition by $55: 45 \mathrm{v} / \mathrm{v}$, the retention time was differed by nearly $8 \%-10 \%$ and the peaks were located primarily at 2.143 and 3.147 minutes (Fig. 4b). As the flow rate was enhanced by $0.1 \mathrm{ml} /$ minute, the peaks emerged at 2.138 and 3.147 minutes (Fig. 4c). In contrast, the reduction in the flow rate by similar magnitude produced retention at 2.142 and 3.151 minutes (Fig. 4d). With an increase in the flow rate, the compound appeared earlier in the chromatogram whereas vice-versa phenomenon was observed when the flow rate was decreased. The disparity in the column temperature by $5^{\circ} \mathrm{C}$ produced retention peaks at 2.134 and 3.140 minutes at $35^{\circ} \mathrm{C}$ (Fig. 4e) whereas 2.141 and 3.150 minutes when the temperature was maintained at $25^{\circ} \mathrm{C}$ (Fig. 4f). The tailing factor was found to be $<2 \%$ and the plate count was recognized to be $>2,000$, therefore matching the minimum requirements of the USP pharmacopeia (Table 5). In all the studies, the deliberate change in the parameters leads to an appearance of the peaks in a very close range of 2.132-2.143 minutes for IVA and 3.135-3.151 for MET which certainly indicated that the developed method possesses robust attributes.

\section{System suitability parameters}

The system suitability parameters of the developed method demonstrated a high degree of reproducibility and can be employed for the routine analysis of the drug combination. For IVA, the developed method expressed average retention time $\left(R_{t}\right)$ of 2.287 minutes along with mean theoretical plates (TP) of 3,618 . The $R_{t}$ and TP were perceived to be 3.521 minutes and 5,760 in the case of MET (Table 6). The tailing factor of $<2 \%$ signified no specific tailing in both cases. Good peak symmetry (asymmetric factor $=1$ ) represented an ideal Gaussian peak where both the factors (symmetric and asymmetric) were of equal magnitude. A noteworthy resolution, significant separation, high column efficacy, and better reproducibility of the developed method can be judged from the fact that it met the minimum requirements of monographs of US Pharmacopoeia (minimum theoretical plates of 2,000 and tailing factor $<2 \%$ ). The separation factor $(\alpha)$ and resolution factor $\left(R_{s}\right)$ were found

Table 5. Robustness study of IVA and MET.

\begin{tabular}{ccccc}
\hline Parameter varied & $\begin{array}{c}\text { Retention } \\
\text { time }\end{array}$ & Peak area & $\begin{array}{c}\text { USP plate } \\
\text { count }\end{array}$ & USP tailing \\
\hline \multicolumn{4}{c}{ Ivabradine } \\
\hline Mobile phase $65: 35 \mathrm{v} / \mathrm{v}$ & 2.132 & 351,761 & 3,283 & 1.45 \\
Mobile phase $55: 45 \mathrm{v} / \mathrm{v}$ & 2.143 & 350,038 & 3,665 & 1.47 \\
Flow rate $0.9 \mathrm{ml} /$ minute & 2.138 & 350,566 & 3,345 & 1.48 \\
Flow rate $0.7 \mathrm{ml} /$ minute & 2.142 & 353,438 & 3,786 & 1.51 \\
Column temperature $35^{\circ} \mathrm{C}$ & 2.134 & 353,220 & 3,397 & 1.46 \\
Column temperature $25^{\circ} \mathrm{C}$ & 2.141 & 354,250 & 3,892 & 1.46 \\
& \multicolumn{7}{c}{ Metoprolol } & & 1.34 \\
\hline Mobile phase $65: 35 \mathrm{v} / \mathrm{v}$ & 3.135 & $2,403,611$ & 5,904 & 1.35 \\
Mobile phase $55: 45 \mathrm{v} / \mathrm{v}$ & 3.151 & $2,415,903$ & 5,702 & 1.36 \\
Flow rate $0.9 \mathrm{ml} / \mathrm{minute}$ & 3.147 & $2,398,045$ & 5,346 & 1.37 \\
Flow rate $0.7 \mathrm{ml} / \mathrm{minute}$ & 3.151 & $2,401,986$ & 5,557 & 1.34 \\
Column temperature $35^{\circ} \mathrm{C}$ & 3.140 & $2,410,497$ & 5,796 & 1.35 \\
Column temperature $25^{\circ} \mathrm{C}$ & 3.150 & $2,417,631$ & 5,526 & \\
\hline
\end{tabular}


Table 6. Systems suitability parameters.

\begin{tabular}{|c|c|c|c|c|c|c|c|c|c|c|c|}
\hline \multicolumn{7}{|c|}{ IVA } & \multicolumn{5}{|c|}{ MET } \\
\hline $\begin{array}{c}\mathbf{R t} \\
(\min )\end{array}$ & Area $(m V)$ & $\begin{array}{l}\text { Theoretical } \\
\text { plates (TP) }\end{array}$ & $\begin{array}{l}\text { Separation } \\
\text { factor }\end{array}$ & $\begin{array}{l}\text { Resolution } \\
\text { factor }\end{array}$ & $\begin{array}{l}\text { Tailing } \\
\text { factor }\end{array}$ & $\begin{array}{c}\mathbf{R t} \\
\text { (minute) }\end{array}$ & $\begin{array}{l}\text { Area } \\
(\mathrm{mV})\end{array}$ & $\begin{array}{l}\text { Theoretical } \\
\text { plates (TP) }\end{array}$ & $\begin{array}{l}\text { Separation } \\
\text { factor }\end{array}$ & $\begin{array}{l}\text { Resolution } \\
\text { factor }\end{array}$ & $\begin{array}{l}\text { Tailing } \\
\text { factor }\end{array}$ \\
\hline 2.285 & 378,053 & 3,504 & 1.536 & 1.932 & 1.45 & 3.512 & $2,516,517$ & 5,656 & 1.536 & 1.891 & 1.34 \\
\hline 2.287 & 377,337 & 3,641 & 1.536 & 1.931 & 1.44 & 3.515 & $2,512,491$ & 5,555 & 1.536 & 1.899 & 1.35 \\
\hline 2.287 & 379,967 & 3,881 & 1.537 & 1.928 & 1.53 & 3.516 & $2,521,645$ & 5,885 & 1.537 & 1.893 & 1.34 \\
\hline 2.288 & 378,516 & 3,764 & 1.538 & 1.921 & 1.51 & 3.520 & $2,517,892$ & 5,583 & 1.538 & 1.894 & 1.35 \\
\hline 2.289 & 375,014 & 3,505 & 1.539 & 1.929 & 1.47 & 3.524 & $2,517,961$ & 5,893 & 1.539 & 1.889 & 1.36 \\
\hline 2.290 & 375,405 & 3,415 & 1.545 & 1.927 & 1.47 & 3.539 & $2,522,600$ & 5,987 & 1.545 & 1.892 & 1.33 \\
\hline $\begin{array}{c}2.287 \\
\text { (Mean) }\end{array}$ & $\begin{array}{c}377,382 \\
\text { (Mean) }\end{array}$ & $\begin{array}{c}3,618 \\
\text { (Mean) }\end{array}$ & $\begin{array}{c}1.538 \\
\text { (Mean) }\end{array}$ & $\begin{array}{l}1.928 \\
\text { (Mean) }\end{array}$ & $\begin{array}{l}1.478 \\
\text { (Mean) }\end{array}$ & $\begin{array}{c}3.521 \\
\text { (Mean) }\end{array}$ & $\begin{array}{c}2,518,184 \\
\text { (Mean) }\end{array}$ & $\begin{array}{c}5,760 \\
\text { (Mean) }\end{array}$ & $\begin{array}{c}1.538 \\
\text { (Mean) }\end{array}$ & $\begin{array}{c}1.893 \\
\text { (Mean) }\end{array}$ & $\begin{array}{l}1.345 \\
\text { (Mean) }\end{array}$ \\
\hline$\%$ RSD & & 0.08 & & & & & & & 0.28 & & \\
\hline
\end{tabular}

to be significantly high as mentioned in the minimum $\mathrm{ICH}$ limits and requirement guidelines of 1 and 1.5, respectively, which concluded that the proposed analytical method produces better separation of both the peaks with reduced tailing and better resolution. Therefore, the method can be employed for the routine analysis owing to high precision, reproducibility, and accuracy attributes.

\section{Limit of detection and quantification}

The LOD and LOQ of IVA were observed to be 0.38 and $0.69 \mu \mathrm{g} / \mathrm{ml}$, whereas for MET it was found to be 0.27 and $0.71 \mu \mathrm{g} /$ $\mathrm{ml}$, respectively, which signified towards the tremendous detection ability of the method for the lowest possible concentration of the solute simultaneously from the combination or formulation.

\section{Forced degradation studies}

The forced degradation study of both the molecules in combination revealed possible degradation under the influence of peroxide, thermal environment, and base treatment. However, the

Table 7. Forced degradation profile of IVA and MET.

\begin{tabular}{cccccc}
\hline $\begin{array}{c}\text { Parameter } \\
\text { varied }\end{array}$ & $\begin{array}{c}\text { Retention } \\
\text { time }\end{array}$ & Peak area & \% peak area & $\begin{array}{c}\text { USP plate } \\
\text { count }\end{array}$ & USP tailing \\
\hline \multicolumn{5}{c}{ Oxidative stress-induced degradation } \\
IVA & 2.269 & 327,652 & 12.337 & 3,144 & 1.31 \\
MET & 3.278 & $2,316,102$ & 87.208 & 5,577 & 1.32 \\
PEAK-1 & 2.655 & 12,097 & 0.455 & 9,542 & 1.01 \\
& & Thermal-induced degradation & & \\
IVA & 2.239 & 344,907 & 12.579 & 3,565 & 1.31 \\
MET & 3.275 & $2,395,316$ & 86.835 & 5,946 & 1.32 \\
PEAK-1 & 4.050 & 1,609 & 0.586 & 9,629 & 1.13 \\
& \multicolumn{5}{c}{ Base-induced degradation } \\
IVA & 2.249 & 327,346 & 11.946 & 3,262 & 1.31 \\
MET & 3.205 & $2,281,899$ & 83.274 & 1,806 & 1.32 \\
PEAK-1 & 2.653 & 39,805 & 1.453 & 1,806 & 0.90 \\
PEAK-2 & 5.072 & 91,190 & 3.327 & 51,871 & 1.02 \\
& & Acid-induced degradation & & \\
IVA & 2.240 & 345,113 & 12.592 & 3,442 & 1.41 \\
MET & 3.277 & $2,395,482$ & 87.408 & 5,911 & 1.33 \\
\hline
\end{tabular}

compounds were resistant to the acidic treatment as no degraded products were observed in the chromatogram (Table 7). The treatment with hydrogen peroxide produced oxidative stress, which resulted in an acute shift of retention peaks of IVA and MET to 2.269 and 3.278 minutes along with the emergence of a degraded compound at 2.665 minutes $(<0.5 \%$ of the total drug content) (Fig. 5a). When the combination was exposed to the thermal stress, a degraded material at 4.050 minutes $(<0.005 \%$ of the total drug content) was observed in the chromatogram along with an alteration in the retention of IVA and MET at 2.239 and 3.275 minutes (Fig. 5b). The treatment under basic condition produced degradation of the compound to most severe form as suggested from the two prominent peaks at 2.653 minutes $(<1.5 \%$ of the total drug content) and 5.072 minutes $(<3.5 \%$ of the total drug content) along with drug peaks at 2.249 and 5.072 minutes (Fig. 5c). The degradation mechanism may be due to the mechanistic abstraction of the proton by the base $\left(\mathrm{OH}^{*}\right)$ radical from the compound by cleaving the weak bond between the alpha proton and the carbon atom. No degradant peaks were observed in the chromatogram under the acidic conditions, but a change in the retention time of the drugs was seen at 2.240 and 3.277 minutes,
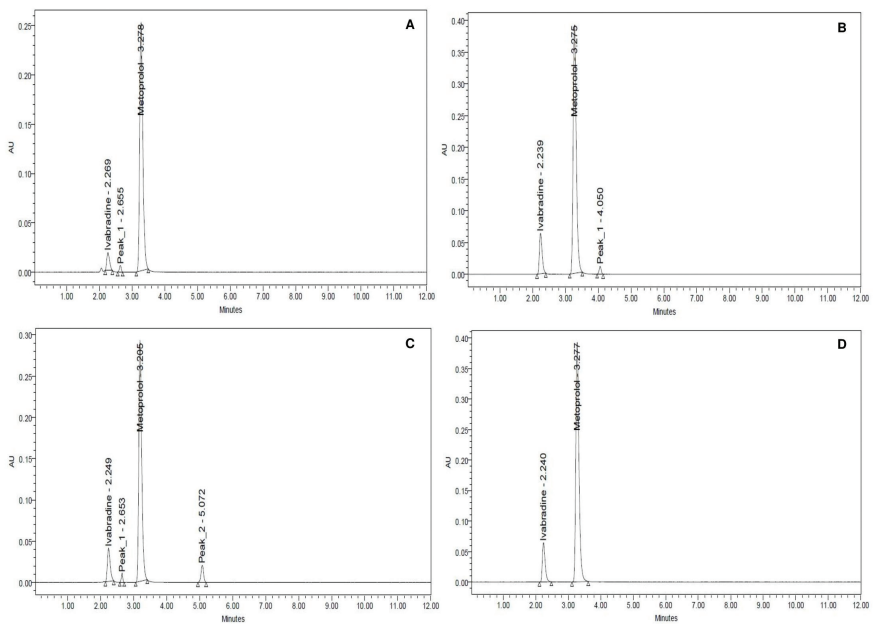

Figure 5. Force degradation studies of ivabradine and metoprolol under (a) peroxide; (b) thermal condition; (c) basic treatment; and (d) acidic environment. 
respectively (Fig. 5d). However, from the study, it was noticed that MET remained quite resistant as the retention time differed in a minimum amount. The future plans of the study will involve correct establishment of the chemical structures of the quantified degraded materials by using sophisticated techniques like LC-MS or GC-MS which will help in providing better quality control and quality assurance attributes for pharmaceutical industries.

\section{CONCLUSION}

The developed analytical method can be employed for the simultaneous estimation of IVA and MET in both bulk and tablet formulation. The ICH guidelines for validation indicated that the method has linearity over the range, accuracy, precision, and robustness. The $\% \mathrm{RSD}$, theoretical plates, and tailing values complied with the minimum requirements of monographs of US Pharmacopoeia. The validated stress degradation studies under thermal, oxidative, alkali, and acid presented the possible degraded components which will be of great importance to the chemists for quality control and assurance purpose. The method can be employed for the routine analysis owing to high precision, reproducibility, and accuracy attributes.

\section{ACKNOWLEDGMENT}

Mr. S. B. Kanthale is highly thankful to his supervisor Prof. S. S. Thonte and School of Pharmacy, Swami Ramanand Teertha Marathwada University, Nanded, India.

\section{CONFLICT OF INTEREST}

No conflict of interest declared.

\section{FINANCIAL SUPPORT}

None.

\section{REFERENCES}

Bauer LC, Santana DD, Macedo MD, Torres AG, Souza NE, Simionato JI. Method validation for simultaneous determination of cholesterol and cholesterol oxides in milk by RP-HPLC-DAD. J Braz Chem Soc, 2014; 25(1):161-8.

Cui XY, Shi XJ, Li ZD, Zhong MK. Determination of ivabradine in rat plasma by a validated HPLC with fluorescence detection. Chinese Pharm J, 2010; 4:024.

Deodhe ST, Dhabarde DM, Kamble MA, Mahapatra DK. Novel stability indicating RP-HPLC method for the estimation of Pinaverium bromide in tablet formulation: assay development and validation. Eur J Anal Chem, 2017a; 12(2):3-16.

Deodhe ST, Dhabarde DM, Kamble MA, Mahapatra DK. Development and validation of a novel stability indicating RP-HPLC method for the estimation of Entecavir in tablet formulation. Eur J Anal Chem, 2017b; 12(3):223-35

DiFrancesco D, Camm JA. Heart rate lowering by specific and selective I f current inhibition with ivabradine. Drugs, 2004; 64(16):1757-65.

Gokhroo RK, Priti K, Ranwa BL, Anantharaj A, Kishor K, Pandey $\mathrm{S}$, Roy R. Comparison of ivabradine and metoprolol in patients with acute inferior wall myocardial infarction: expanding arena for ivabradine. J Am Coll Cardiol, 2016; 67(13S):535

Jha SK, Bhaskaran S, Kamble MA, Mahapatra DK. A novel RPHPLC based assay for the estimation of tramadol $\mathrm{HCl}$ content in tablets: development and validation. Inventi Impact Pharm Anal Qual Assur, 2017; 2017(4):142-6.
Kaski JC, Gloekler S, Ferrari R, Fox K, Lévy BI, Komajda M, Vardas P, Camici PG. Role of ivabradine in management of stable angina in patients with different clinical profiles. Open Heart 2018; 5(1):e000725.

Li N, Shi XJ, Zhang ZL, Zhong MK. Determination of ivabradine and its active metabolite $\mathrm{N}$-desmethylivabradine in rat plasma by HPLC and their pharmacokinetic study. Chinese Pharm J, 2011; 15:019.

Maheshwari S, Khandhar AP, Jain A. Quantitative determination and validation of ivabradine $\mathrm{HCl}$ by stability indicating RP-HPLC method and spectrophotometric method in solid dosage form. Eur J Anal Chem, 2010; 5(1):53-62.

Mostafa NM, Fayez YM, Farid JF, Abd El-Alim AE. Stability indicating spectrophotometric methods for determination of ivabradine hydrochloride in the presence of its degradation product. Anal Chem Lett, 2017; 7(2):280-94

Patra S, Panda S. Rapid and selective UV spectrophotometric and RP-HPLC methods for dissolution studies of ivabradine controlled-release formulations. Pharma Tutor, 2014; 2(8):201-13.

Perumal SS, Ekambaram SP, Raja S. Analytical method development and validation of simultaneous estimation of rabeprazole, pantoprazole, and itopride by reverse-phase high-performance liquid chromatography. J Food Drug Anal, 2014; 22(4):520-6.

Prakash O, Mahapatra DK, Singh R, Singh N, Verma N, Ved A. Development of a new isolation technique and validated RP-HPLC method for Quercetin and Kaempferol from Azadirachta indica leaves. Asian J Pharm Anal, 2018; 8(3):164-8.

Ptaszynski P, Kaczmarek K, Ruta J, Klingenheben T, Cygankiewicz I, Wranicz JK. Ivabradine in combination with metoprolol succinate in the treatment of inappropriate sinus tachycardia. J Cardiovasc Pharmacol Therapeut, 2013; 18(4):338-44

Ranjha NM, Majeed A, Hussain I, Fawad Rasool M. Quantitative determination and validation of ivabradine- $\mathrm{HCl}$ in pharmaceutical formulation and rabbit plasma by high performance liquid chromatography method. Curr Pharm Anal, 2017; 13(5):446-51.

Rehman M, Nagamallika G. Validated rp-hplc method for the determination of ivabradine hydrochloride in pharmaceutical formulation. Int J Pharm Sci Drug Res, 2017; 9(5):228-33.

Sawale V, Dhabarde DM, Mahapatra DK. Development and validation of UV spectrophotometric method for simultaneous estimation of olmesartan medoxomil and chlorthalidone in bulk and tablet. Eur J Anal Chem, 2017; 12(1):55-66.

Seerapu S, Srinivasan BP. Development and validation of RPHPLC method for the estimation of ivabradine hydrochloride in tablets. Indian J Pharm Sci, 2010; 72(5):667-71.

Sun W, Chen R, Li W, Zhang H, Ye J, Cui X, Huang C. Simultaneous determination of ivabradine, metoprolol and their metabolites in rat plasma by ultra-performance liquid chromatography tandem mass spectrometry and its application in a pharmacokinetic study. Anal Method, 2015; 7(19):8459-65.

Volterrani M, Iellamo F. Complementary and synergic role of combined beta-blockers and ivabradine in patients with chronic heart failure and depressed systolic function: a new therapeutic option? Cardiac Failure Rev, 2016; 2(2):130.

Werdan K, Ebelt H, Nuding S, Höpfner F, Stöckl G, MüllerWerdan U; ADDITIONS Study Investigators. Ivabradine in combination with metoprolol improves symptoms and quality of life in patients with stable angina pectoris: a post hoc analysis from the ADDITIONS trial. Cardiology, 2016; 133(2):83-90.

Zarifis J, Kallistratos M, Katsivas A, investigators of the Prospective, Non-interventional, Observational Study of the Antianginal Efficacy of Ivabradine During a 4-Month Treatment of a Greek Population With Coronary Artery Disease. Antianginal efficacy of ivabradine/ metoprolol combination in patients with stable angina. Clin Cardiol, 2016; 39(12):697-702. 
Zoerner AA, Schroeder C, Kayacelebi AA, Suchy MT, Gutzki FM, Stichtenoth DO, Tank J, Jordan J, Tsikas D. A validated, rapid UPLCMS/MS method for simultaneous ivabradine, reboxetine, and metoprolol analysis in human plasma and its application to clinical trial samples. J Chromatograph, 2013; 927:105-11.

\section{How to cite this article:}

Kanthale SB, Thonte SS, Mahapatra DK. Stability indicating RP-HPLC method for the simultaneous estimation of ivabradine and metoprolol in bulk and tablet formulation. $\mathrm{J}$ Appl Pharm Sci, 2019; 9(04): 137-144. 